\section{Scripps' partnering rethink}

\section{By Lev Osherovich, Senior Writer}

Following a long run of funding a substantial portion of its research through institute-wide deals with pharmas, The Scripps Research Institute is now shifting to more focused collaborations with midsize biotechs. Scripps believes biotechs are a better fit for the institute's platform technologies than pharmas, where platforms can get lost in the companies' disease-oriented franchise structure.

Over the last two decades, Scripps has had a sequential series of campus-wide partnerships with pharmas including Eli Lilly and Co., Johnson \& Johnson, Novartis AG and, most recently, Pfizer Inc.

Under the 2007 Pfizer deal, the pharma had right of first refusal to technology emerging from Scripps' 280 labs at its main campus in La Jolla and its drug discovery institute in Florida. In exchange, the institute received $\$ 100$ million over 5 years and retained royalty rights to products emerging from the collaboration.

Scott Forrest, VP of business development at Scripps, said Pfizer and the institute will continue collaborating in certain undisclosed areas, but the pharma will no longer have preferred access to new Scripps discoveries.

"Historically, we've always had a broad agreement with a major pharma," said Forrest. "Those relationships were a mix of sponsored research and flat payments in exchange for the right to license Scripps' technology. We discovered empirically that those deals were great at providing short-term access to cash, but not all of the technologies we produced were amenable to pharma in-licensing."

At its end, the Scripps-Pfizer deal is a case study in how ill-defined academic-industry collaborations can lead to lost opportunities for both sides.

Mathew Mitchell, technology licensing officer at Scripps and manager of the Pfizer alliance, said that the company ultimately in-licensed very little Scripps technology over the course of the deal.

Mitchell said Pfizer gave Scripps carte blanche for spending the upfront money on salary support and new facilities, but the pharma did not specify what it was hoping to get from Scripps.

The Pfizer deal called for Scripps to file technology disclosures with the pharma on everything coming out of the institute, but Mitchell said the review process for disclosures was not clearly structured and could take months to complete.
Mitchell added that one of the most fruitful collaborations with Pfizer was in high throughput screening at the Scripps Florida drug discovery institute. Those projects had clearly defined aims and focused on compounds rather than new technology.

In retrospect, Mitchell suspects that because Pfizer and Scripps did not clearly communicate up front about what sort of technologies the pharma wanted, the deal "didn't bear the fruit that it could have."

Forrest said the disease-focused structure of pharmas proved to be a barrier to entry for Scripps' core technologies, which include platforms for target discovery, protein engineering and drug screening.

During the genomics bubble, most companies forged multiple platform technology deals, often creating overarching tool groups designed to serve their therapeutic area groups. Forrest said those days are over, as anticipated declines in revenue due to patent expiry have driven aggressive cost cutting in research areas without an immediate path to market.

"For us or any early stage research alliance with pharma, the money available for projects" has diminished, said Forrest. "We're a part of their research spending, and we ended up on the wrong side of their cost-cutting equation."

One major obstacle in working with Pfizer was the pharma's inability to convey Scripps' technologies to the right people within the company, said Forrest.

"Platform technologies are very difficult for large companies to position internally," said Forrest. "Pharmas are siloed by therapeutic areas, but platforms are usually applicationagnostic at an early stage. These technologies often have data packages that pharma licensing offices don't know how to interpret."

Forrest thinks Scripps will be better served by not giving any one company the exclusive right to license all of the institute's technology. He said the ideal industry partner going forward would be a "midsize company with positive cash flow and a relatively narrow focus."

Compared with fledgling startups and big companies, midsize companies are in a better position to evaluate and advance Scripps' technologies to market and generate revenue for the institute, said Forrest.

Partnering with nimble but seasoned biotechs will make it easier for Scripps researchers to find and work directly with the right people, he added.

"Under the old structure, not enough of our compounds or technologies were advancing to market," said Forrest. "If we really work together with these companies, we are more likely to hit the market."

Another potential partnering scenario is a disease-focused collaborative research program like the December 2010 and January 2011 deals the Sanford-Burnham Medical Research Institute made with the pharmas Takeda Pharmaceutical Co. Ltd. and J\&J, respectively, Forrest said. The J\&J deal covers target and drug discovery in Alzheimer's disease (AD) and neuropsychiatric disorders, whereas the Takeda deal covers obesity. ${ }^{1}$

Scripps will continue to host the Genomics Institute of the Novartis 
Research Foundation (GNF), a Novartis-backed research outfit that predates the Pfizer deal.

\section{Getting a head}

Scripps' change in partnering strategy coincides with a change of leadership. At the start of the year, Michael Marletta became president of the institute in addition to professor of chemistry. He formerly was chair of chemistry at the University of California, Berkeley.

Marletta told SciBX that fundraising for discovery science, which he said is a strength of Scripps, has become harder than fundraising for translational research. He noted that constrained research and partnering budgets at pharmas have led to a more milestone-driven, disease-focused attitude toward academic collaborators.

"Pharmas have changed how they invest and think about research," said Marletta. "Their interest in places like Scripps was previously something like, 'Here's a bunch of money, go off and do your own thing, and we'll have a chance to look at it'. Now they're much more targeted, to the detriment of discovery science."

Marletta noted that the end of the Pfizer deal also comes at a time when government support for basic research is diminishing, thus putting further stress on Scripps' finances.

"The support of pharmas and the federal government has allowed Scripps to undergo unprecedented growth, but both of these partners are disappearing on us," Marletta noted.

Marletta said Scripps will make up some of the lost money from royalties on drugs based on Scripps technology. He expects the coming years will bring a significant uptick in royalty income from Benlysta belimumab from GlaxoSmithKline plc and Human Genome Sciences Inc. and Pfizer's Vyndaqel tafamidis.

Benlysta was approved last year to treat active, autoantibody-positive systemic lupus erythematosus (SLE) in patients who are receiving standard therapy. Vyndaqel, a small molecule that corrects a structural defect in a mutant form of transthyretin, was approved last year in the
EU for familial amyloid polyneuropathy. In April 2011, the FDA issued a refusal to file letter for Vyndaqel.

Vyndaqel was developed by FoldRx Pharmaceuticals Inc., which was cofounded by Jeffery Kelly, a chemistry professor at Scripps. FoldRx was based on IP developed prior to the Pfizer deal, and Pfizer subsequently acquired FoldRx for an undisclosed amount in 2010.

Marletta also hopes to derive more income from increased licensing. He said Scripps plans to scale up its technology transfer office staffing to handle a higher volume of IP filings. Rather than routinely handing its technology over to Pfizer, the office now will need to proactively seek out potential partners.

"We're going to increase the revenue that Scripps generates from its IP," said Marletta. "We're going to invest in the technology transfer office to handle the greater workload, and to justify that expense there needs to be more income."

He also said Scripps will now seek philanthropic funding, a source of dollars the institute previously had not explored.

Osherovich, L. SciBX 5(3); doi:10.1038/scibx.2012.61

Published online Jan. 19, 2012

\section{REFERENCES}

1. Cain, C. SciBX 4(5); doi:10.1038/scibx.2011.123

\section{COMPANIES AND INSTITUTIONS MENTIONED}

Eli Lilly and Co. (NYSE:LLY), Indianapolis, Ind.

GlaxoSmithKline plc (LSE:GSK; NYSE;GSK), London, U.K.

Human Genome Sciences Inc. (NASDAQ:HGSI), Rockville, Md.

Johnson \& Johnson (NYSE:JNJ), New Brunswick, N.J.

Novartis AG (NYSE:NVS; SIX:NOVN), Basel, Switzerland

Pfizer Inc. (NYSE:PFE), New York, N.Y.

Sanford-Burnham Medical Research Institute, La Jolla, Calif. Scripps Florida, Jupiter, Fla.

The Scripps Research Institute, La Jolla, Calif.

Takeda Pharmaceutical Co. Ltd. (Tokyo:4502), Osaka, Japan University of California, Berkeley, Calif. 